DOI: http://dx.doi.org/10.15688/jvolsu1.2015.1.3

УДК 517.518.823

ББК 22.19

\title{
ВОССТАНОВЛЕНИЕ ПОВЕРХНОСТИ ПО ЕЕ НОРМАЛЯМ В СИСТЕМЕ ТОЧЕК
}

\author{
Величко Елена Вадимовна \\ Кандидат физико-математических наук, доцент, \\ докторант кафедры информационных технологий, \\ Таврический государственный агротехнологический университет \\ velichko_ev@i.ua \\ просп. Б. Хмельницкого, 18, 72310 г. Мелитополь, Запорожская область, Украина
}

Аннотация. Рассматривается задача об аппроксимации функции, заданной в некоторой области из $R^{2}$. Считаются известными нормали к ее графику в системе точек, лежащих в этой области. Искомая функция ищется в виде многочлена от двух переменных, коэффициенты которого минимизируют невязку. Невязка представляет собой сумму квадратов разностей нормалей к заданной и восстанавливающей поверхностям, нормированным таким образом, чтобы их аппликаты равнялись единице. Приводятся численные примеры для алгебраической и трансцендентной функции, которые иллюстрируют эффективность предложенного алгоритма.

Ключевые слова: регулярная поверхность, нормали к поверхности, аппроксимация, метод наименьших квадратов (МНК), функция невязки.

\section{Введение}

В приложениях достаточно часто встречаются задачи восстановления поверхностей по нескольким известным ее точкам [1]. Обычно функция, которая задает поверхность, ищется в виде многочлена от двух переменных, коэффициенты которой находятся методом наименьших квадратов [5]. Другим подходом к этому является аппарат дискретного геометрического моделирования, в котором результатом работы соответствующих алгоритмов выступает дополнительная информация про поверхность на более широком множестве точек при некоторых априорных предположениях об их поведении [6].

В других задачах, таких как восстановление трехмерных объектов по их двумерным изображениям при использовании модели Ламберта, имеется информация о нормалях к поверхности в системе точек [2]. В таких случаях используются сплайны [4; 8; 9].

В данной статье предлагается способ аналитического восстановления поверхности в заданной области. Для кривых подобная задача была решена автором в [3]. Полученные 
результаты могут быть полезны, в частности, при подготовке цифровой модели рельефа местности [7].

\section{1. Постановка задачи}

Рассмотрим следующую задачу. В трехмерном пространстве задана некоторая регулярная поверхность $\Phi$, которая однозначно проектируется на область $D$ координатной плоскости $O X Y$. В области $D$ заданы $n$ точек $A_{i}\left(x_{i}, y_{i}\right), i=1 \ldots n$. В этих точках известны нормали $\bar{v}_{i}$ к поверхности Ф. Ставится задача о нахождении поверхности $\Psi$, которая описывается уравнением $z=f(x, y)$, нормали к которой в точках $A_{i}$ наиболее близки по направлению к векторам $\bar{v}_{i}$. Здесь $f(x, y)$ - полином фиксированной степени $m$ от двух переменных.

Будем считать, что все нормали $\bar{v}_{i}$ выбраны таким образом, что образуют острый угол с положительным направлением оси $O Z$. Так как нас интересуют только направления векторов, а не их длина, то стоит отметить, что они нормированы таким образом, что их третья координата равнялась единице, то есть нормали имеют следующий вид $\bar{v}_{i}=\bar{v}_{i}\left(v_{i 1}, v_{i 2}, 1\right)$. Такое нормирование всегда возможно, иначе не будет выполняться однозначность проектирования.

\section{2. Метод решения}

Функцию $f(x, y)$ запишем в виде:

$$
f(x, y)=\sum_{j, k} a_{j k} x^{j} y^{k}
$$

Тут суммирование проводится по всем таким наборам $(j, k)$, для которых $j, k \geq 0$, $j+k \leq m$.

Перепишем уравнение поверхности $\Psi$ в виде $g(x, y, z)=z-f(x, y)=0$. Нормаль к этой поверхности в точке $A_{i}\left(x_{i}, y_{i}\right)$ параллельна вектору:

$$
\bar{\omega}_{i}=\left.\left(\frac{\partial g}{\partial x}, \frac{\partial g}{\partial y}, \frac{\partial g}{\partial z}\right)\right|_{A_{i}}=\left(-\left.\frac{\partial f}{\partial x}\right|_{A_{i}},-\left.\frac{\partial f}{\partial y}\right|_{A_{i}}, 1\right) .
$$

Таким образом, если нам удалось точно решить поставленную задачу, то должны иметь место следующие равенства:

$$
\bar{\omega}_{i}=\bar{v}_{i}, i=1 \ldots n
$$

которые можно записать в виде:

$$
\sum_{i=1}^{n}\left(\bar{\omega}_{i}-\bar{v}_{i}\right)^{2}=0
$$

Поскольку степень многочлена $f(x, y)$ фиксированная, то речь идет о приближенном решении. В этом случае приведенное выражение не будет равняться нулю. Близость направлений заданных и построенных нормалей будем характеризовать невязкой: 


$$
F=\frac{1}{2} \sum_{i=1}^{n}\left(\bar{\omega}_{i}-\bar{v}_{i}\right)^{2}
$$

которую необходимо минимизировать.

При указанной выше нормировке все векторы $\bar{v}_{i}$ имеют в общем случае разные длины: $\left|\bar{v}_{i}\right|=\frac{1}{\left(\bar{w}_{i}, \bar{e}_{3}\right)}$, где $\bar{w}_{i}$ - единичный вектор, сонаправленный вектору нормали $\bar{v}_{i}, \bar{e}_{3}-$ орт оси $O z$. Таким образом, при выборе такой невязки векторы нормали, имеющие больший угол с вертикальной осью, будут иметь большую длину, и как следствие, будут лучше приближены.

С учетом (1) и (2), в развернутом виде невязка запишется следующим образом:

$$
2 F=\sum_{i=1}^{n}\left(v_{1 i}+\sum_{j, k} j \cdot a_{j k} x_{i}^{j-1} y_{i}^{k}\right)^{2}+\sum_{i=1}^{n}\left(v_{2 i}+\sum_{j, k} k \cdot a_{j k} x_{i}^{j} y_{i}^{k-1}\right)^{2} \rightarrow \min
$$

Количество искомых параметров $a_{j k}$ равно $\frac{m(m+1)}{2}-1$, так как наличие слагаемого $a_{00}$ не влияет на направление нормалей. Для определения этих параметров, согласно методу наименьших квадратов, найдем частные производные от $F$, по ним и приравняем полученные выражения к нулю. В итоге имеем систему:

$$
\frac{\partial F}{\partial a_{s p}}=\sum_{i=1}^{n}\left(\left(v_{1 i}+\sum_{j, k} j \cdot a_{j k} x_{i}^{j-1} y_{i}^{k}\right) s x_{i}^{s-1} y_{i}^{p}+\left(v_{2 i}+\sum_{j, k} k \cdot a_{j k} x_{i}^{j} y_{i}^{k-1}\right)\right) p x_{i}^{s} y_{i}^{p-1}=0 .
$$

Тут $s, p \geq 0, s+p \leq m$. После преобразований получаем систему:

$$
\sum_{j, k} a_{j k}\left(j s R_{j+s-2, k+p}+k p R_{j+s, k+p-1}\right)+s L_{1, s-1, p}+p L_{2, s, p-1}=0
$$

где

$$
R_{\alpha, \beta}=\sum_{i=1}^{n} x_{i}^{\alpha} y_{i}^{\beta}, L_{\gamma, \alpha, \beta}=\sum_{i=1}^{n} v_{i \gamma} x_{i}^{\alpha} y_{i}^{\beta}
$$

Решив (5), получим уравнение, описывающее поверхность $\Psi$.

\section{3. Частный случай $m=2$}

Рассмотрим случай, когда поверхность $\Psi$ описывается многочленом второй степени:

$$
f(x, y)=a_{00}+a_{10} x+a_{01} y+a_{20} x^{2}+a_{11} x y+a_{02} y^{2} .
$$

Система (5) для этого случая имеет такой вид: 


$$
\left\{\begin{array}{l}
a_{10} n+2 a_{20} \sum_{i=1}^{n} x_{i}+a_{11} \sum_{i=1}^{n} y_{i}+\sum_{i=1}^{n} v_{i 1}=0, \\
a_{01} n+2 a_{02} \sum_{i=1}^{n} y_{i}+a_{11} \sum_{i=1}^{n} x_{i}+\sum_{i=1}^{n} v_{i 2}=0, \\
a_{10} \sum_{i=1}^{n} x_{i}+2 a_{20} \sum_{i=1}^{n} x_{i}^{2}+a_{11} \sum_{i=1}^{n} x_{i} y_{i}+\sum_{i=1}^{n} v_{i 1} x_{i}=0, \\
a_{01} \sum_{i=1}^{n} y_{i}+2 a_{02} \sum_{i=1}^{n} y_{i}^{2}+a_{11} \sum_{i=1}^{n} x_{i} y_{i}+\sum_{i=1}^{n} v_{i 2} y_{i}=0, \\
a_{10} \sum_{i=1}^{n} y_{i}+a_{01} \sum_{i=1}^{n} x_{i}+2\left(a_{20}+a_{02}\right) \sum_{i=1}^{n} x_{i} y_{i}+a_{11} \sum_{i=1}^{n}\left(x_{i}^{2}+y_{i}^{2}\right)+ \\
+\sum_{i=1}^{n} v_{i 1} y_{i}+\sum_{i=1}^{n} v_{i 2} x_{i}=0,
\end{array}\right.
$$

и может быть решена любым известным методом.

\section{4. Примеры расчетов}

Пример 1. Возьмем поверхность Ф, заданную уравнением $z=x^{3}+x y+2 y^{2}+x-3 y$, и 5 точек $A_{1}(0,0), A_{2}(1,0), A_{3}(1,1), A_{4}(1,2), A_{5}(2,1)$ Вычислим соответствующие нормали: $\bar{v}_{1}(-1,3,1), \bar{v}_{2}(-4,2,1), \bar{v}_{3}(-5,-2,1), \bar{v}_{4}(-6,-6,1), \bar{v}_{5}(-14,-3,1)$. Записав и решив систему (8), получим такую функцию:

$$
z=3,114 x^{2}+2,082 y^{2}+0,543 x y-0663 x-2,674 y,
$$

для которой соответствующие нормали равны:

$$
\begin{gathered}
\bar{\omega}_{1}(0.663,2.674,1), \bar{\omega}_{2}(-5.565,2.13,1), \bar{\omega}_{3}(-6.109,-2.033,1), \\
\bar{\omega}_{4}(-6.652,-6.196,1), \bar{\omega}_{5}(-12.337,-2.576,1) .
\end{gathered}
$$

На рисунке 1 изображены исходная $\Phi$ и аппроксимирующая ее поверхность $\Psi$. Коэффициент $a_{00}$ выбирался таким образом, чтобы эти поверхности имели общую точку - начало координат. На рисунке 2 изображен график функции, которая является разностью этих двух функций.

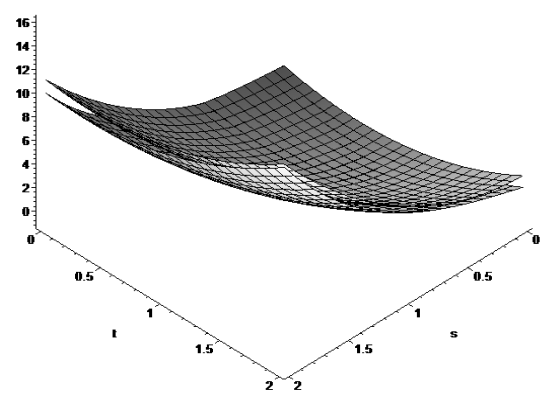

Рис. 1. Поверхности Ф и $\Psi$

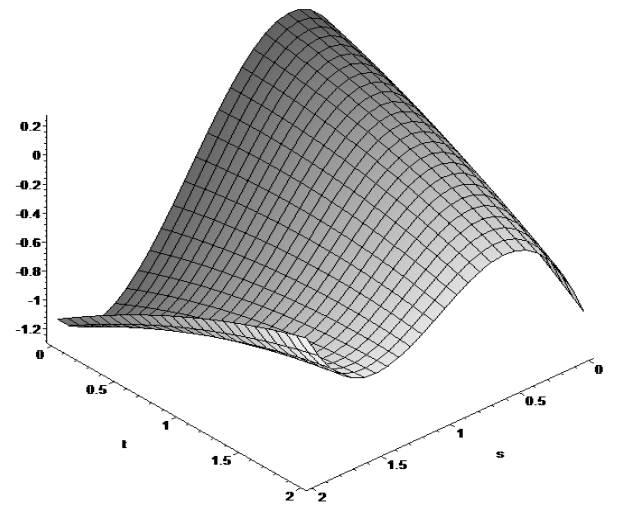

Рис. 2. График разности значений функций 
Пример 2. Рассмотрим поверхность $\Phi$, заданную уравнением $z=\sin ((x-0,5)(y-0,5))$, и 5 точек $A_{1}(0,0), A_{2}(0,1), A_{3}(1,0), A_{4}(1,1), A_{5}(0.5,0.5)$ и вычислим соответствующие нормали: $\bar{v}_{1}(t, t, 1), \bar{v}_{2}(-t, t, 1), \bar{v}_{3}(t,-t, 1), \bar{v}_{4}(-t,-t, 1), \bar{v}_{5}(0,0,1)$. Тут $t \approx 0,484$. Записав и решив систему (8), получим такую функцию: $z=2 t x y-t x-t y$, для которой соответствующие нормали равны:

$$
\bar{\omega}_{1}(t, t, 1), \bar{\omega}_{2}(-t, t, 1), \bar{\omega}_{3}(t,-t, 1), \bar{\omega}_{4}(-t,-t, 1), \bar{\omega}_{5}(0,0,1) .
$$

На рисунке 3 изображены исходная и расчетные поверхности (они практически совпадают). Коэффициент $a_{00}$ брался таким образом, чтобы эти поверхности имели общую точку, которая проектируется в точку $A_{5}(0.5,0.5)$. На рисунке 4 приведен график функции, которая является разностью этих двух функций.

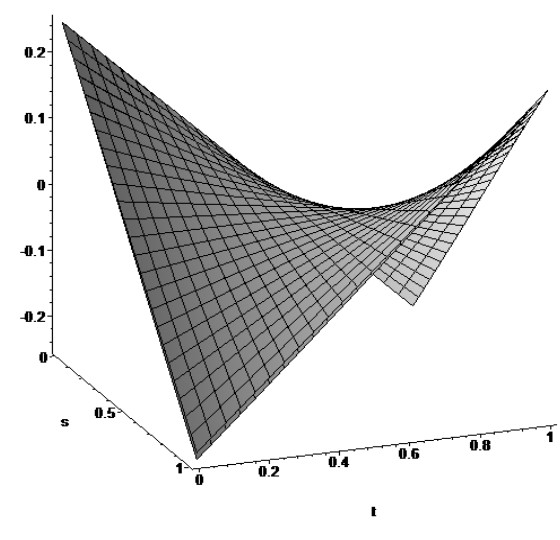

Рис. 3. Поверхности Ф и $\Psi$

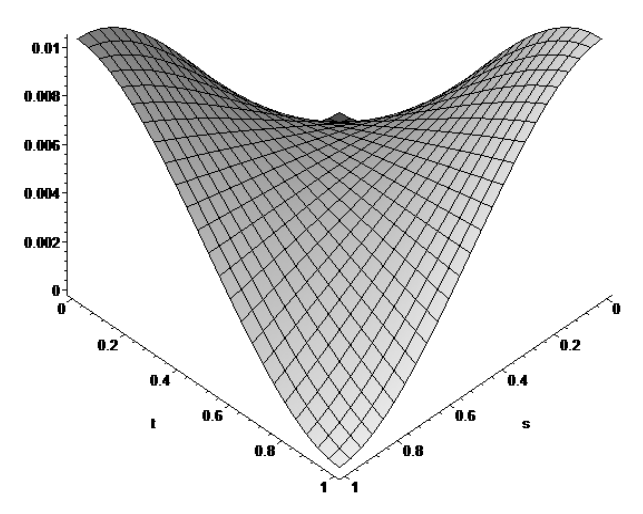

Рис. 4. График разности значений функций

Как видим, в обоих рассмотренных случаях расчетные формулы дают качественное приближение для заданной функции. Заметим, что если функция задана многочленом второй степени, то полученная расчетная функция будет с ней совпадать.

\section{Выводы}

В статье сформулирована задача про аппроксимацию многочленом функции двух переменных по известным нормалям к графику ее поверхности в узлах некоторой сетки. Особенность предложенного метода состоит в нормировке нормалей по аппликате, при которой наилучшая точность аппроксимации достигается на «крутых» участках поверхности. Получена в общем виде система линейных алгебраических уравнений относительно коэффициентов многочлена. Численные примеры приведены для многочленов второй степени и иллюстрируют хорошую степень восстановления. 


\section{СПИСОК ЛИТЕРАТУРЫ}

1. Бердышев, В. И. Аппроксимация функций, сжатие численной информации, приложения / В. И. Бердышев, Л. В. Петрак. - Екатеринбург : Изд-во УрО РАН, 1999. - 296 с.

2. Вежневец, В. Задача восстановления формы объекта по закраске (shape from shading) / В. Вежневец // Компьютерная графика и мультимедиа. - 2004. - Вып. № 2 (1). - Электрон. текстовые дан. - Режим доступа: http://cgm.computergraphics.ru/content/view/59. - Загл. с экрана.

3. Величко, О. В. Відновлення кривої за ії нормалями в системі точок / О. В. Величко, В. М. Малкіна // Праці Таврійського державного агротехнологічного університету. - Мелітополь : ТДАТУ, 2014. - Т. 2, вип. 14. - С. 134-138.

4. Костюк, Ю. Л. Визуально гладкая аппроксимация однозначной поверхности, заданной нерегулярным набором точек / Ю. Л. Костюк, А. Л. Фукс // Геоинформатика. - 2000. - С. 41-45.

5. Лоусон, Ч. Численное решение задач метода наименьших квадратов. (Solving Least Squares Problems) / Ч. Лоусон, Р. Хенсон. - М. : Наука. Гл. ред. физ.-мат. лит., 1986. - 232 с.

6. Найдиш, В. М. Основи прикладної геометрії (навчальний посібник) // В. М. Найдиш, А. В. Найдиш, В. М. Верещага, В. М. Малкіна. - Мелітополь, 2007. - 194 с.

7. Писарев, А. В. Веб-ориентированная система подготовки цифровой модели рельефа местности / А. В. Писарев, М. В. Елисеева // Вестник Волгоградского государственного университета. Серия 1, Математика. Физика. - 2014. - № 1 (20). - С. 46-52.

8. Чопик, П. Відновлення 3D форми поверхні за даними про напівтони / П. Чопик, Б. Русин // Проблеми та перспективи наук в умовах глобалізації: Матеріали IX Всеукраїнської наукової конференції. Тернополь : ТНПУ ім. В. Гнатюка, 2013. - С. 245-250.

9. Doi, M. Three-dimensional mesh generation of an object from an image by shape-from-shading and ellipsoidal bubble mesh method / M. Doi, Y. Takabe // Proc. SPIE 6499. Vision Geometry XV. 649908. - January 29, 2007. - Doi: http://dx.doi.org/10.1117/12.703903.

\section{REFERENCES}

1. Berdyishev V.I., Petrak L.V. Approksimatsiya funktsiy, szhatie chislennoy informatsii, prilozheniya [Approximation of Functions, Numerical Data Compression, Applications]. Ekaterinburg, UrO RAN Publ., 1999. $296 \mathrm{p}$.

2. Vezhnevets V. Zadacha vosstanovleniya formyi obyekta po zakraske (shape from shading) [The Task of Restoring the Object's Shape by Shading (Shape From Shading)]. Kompyuternaya grafika i multimedia [Computer graphics and multimedia]. 2004, vol. 2 (1). Available at: http://cgm.computergraphics.ru/content/view/59.

3. Velichko O.V., Malkina V.M. Vidnovlennya krivoyi za yiyi normalyamy v systemi tochok [Recovery Curve for the System of Normals Points]. Pratsi TDATU [Proceedings of TSAU], 2014, Iss. 14, vol. 2, pp. 134-138.

4. Kostyuk Yu.L., Fuks A.L. Vizualno gladkaya approksimatsiya odnoznachnoy poverhnosti, zadannoy neregulyarnyim naborom tochek [Visually Smooth Approximation of Surface Uniquely Defined Set of Irregular Points]. Geoinformatika [Geoinformatics], 2000, pp. 41-45.

5. Louson Ch., Henson R. Chislennoe reshenie zadach metoda naimenshih kvadratov. (Solving Least Squares Problems) [Numerical Solution of the Least Squares Method (Solving Least Squares Problems)]. Moscow, Nauka Publ., 1986. 232 p.

6. Naydish V.M., Naydish A.V., Vereschaga V.M., Malkina V.M. Osnovy prikladnoy geometrii (navchalniy posibnik) [Fundamentals of Applied Geometry (Manual)]. Melitopol, 2007. 194 p.

7. Pisarev A.V., Eliseeva M.V. Veb-orientirovannaya sistema podgotovki tsifrovoy modeli relyefa mestnosti [Web-Based System of Preparation Digital Models of Terrain]. Vestnik Volgogradskogo gosudarstvennogo universiteta. Seriya 1, Matematika. Fizika [Science Journal of Volgograd State University. Mathematics. Physics], 2014, no. 1 (20), pp. 46-52.

8. Chopik P., Rusin B. VIdnovlennya 3D formy poverhni za danymy pro napivtony [Recovering 3D Forms Surface by Data on the Halftones] Problemy ta perspektyvy nauk $v$ umovah globalizatsiyi: Materialy IX Vseu- 
krayinskoy naukovoy konferentsii [The Problems and Prospects of Science in the Conditions of Globalization: Proceedings of the $9^{\text {th }}$ All-Ukrainian Scientific Conference]. Ternopol, 2013, pp. 245-250.

9. Doi M., Takabe Y. Three-Dimensional Mesh Generation of an Object From an Image by Shape-FromShading and Ellipsoidal Bubble Mesh Method. Proc. SPIE 6499. Vision Geometry XV. 649908, 2000, January 29. Doi: http://dx.doi.org/10.1117/12.703903.

\title{
RECOVERY OF SURFACE FROM ITS NORMALS IN THE SYSTEM OF POINTS
}

\section{Velichko Elena Vadimovna}

Candidate of Physical and Mathematical Sciences, Associate Professor, Candidate for a Doctor's Degree, Department of Information Technologies,

Tavria State Agrotechnological University

velichko_ev@i.ua

Prosp. B. Khmelnitskogo, 18, 72310 Melitopol, Ukraine

\begin{abstract}
The author studies the problem of approximation of functions defined in a domain of $R^{2}$. In the system of points which lies in this domain, the normals to the surface are known. The normals are selected by such a way, so that they form an acute angle with the positive direction of Z-axis. The searched function is looked for in the form of a polynomial in two variables, the coefficients that minimize the discrepancy. The discrepancy is the sum of squares of the differences of the normals to the set and restoring surfaces.

The normals are normalized so that their applicate is equal to 1 . In this case normals, which have a greater angle with the vertical axis, will have a greater length, hence be better approximated. There is the system of linear algebraic equations for the unknown parameters, determined that, completely restores the searched surface. For the uniqueness of recovery is set in one of the points of the domain.

The article is also considering a polynomial in the second degree. In this case, the system is aimed for finding the unknown parameters is greatly simplified.

There are numerical examples for algebraic and transcendental functions. According to the obtained normals, the surface is restored, that approximates the original.

In the second case the surface is taken, which comprises a sine equation. Just consider the case of the five normals. Element that does not contain the degrees have been chosen from the test match conditions and restored function at the origin. Drawings, which show the test surface and the surface, their approximate. Within the accuracy of the drawings, they are practically the same. In both of the above examples of numerical calculation formulas give a qualitative approach for a given function. Note that if the function is given by a polynomial of the second degree, and the amount is no less than five normals, the resulting estimated function will coincide with it.
\end{abstract}

Key words: regular surface, normals to the surface, approximation, Least Square Method (LSM), misalignment function. 